\title{
BETWEEN SHOW TRIALS AND SHAM PROSECUTIONS: THE ROME STATUTE'S POTENTIAL EFFECT ON DOMESTIC DUE PROCESS PROTECTIONS
}

\begin{abstract}
This article examines the extent to which the International Criminal Court influences national jurisdictions with respect to due process protections. An analysis of two of the Rome Statute's safeguards against failing national justice systems, namely the admissibility criteria found in Article 17 and Article 20(3) show that the Court's influence may extend to domestic due process rights. The Rome Statute's complementarity principle leaves room for such an interpretation, inter alia, by demanding regard to due process as recognized by international law when the Court assesses admissibility. A liberal interpretation of this idea is known as the due process thesis. However, the author suggests a narrower approach, only in cases of gross violations of core fair trial rights. Then, the article examines how this moderate form of the due process thesis might affect evidentiary rules. The reason for this is twofold. First, most evidentiary rules can be construed as a form of due process protection, rendering them a comprehensive area of law suitable for examination. Second, evidentiary issues are inseparable from the practical impediments with respect to fact-finding, which are currently widely discussed in the international criminal justice discourse.
\end{abstract}

\section{INTRODUCTION}

On 19 November 2011, Libyan authorities captured Saif al-Islam Gaddafi, son of Libya's former leader Muammar Gaddafi. ${ }^{1}$ Shortly

* PhD Candidate, Department of Criminal Law and Criminology, VU University Amsterdam. The author wishes to thank Professors Elies van Sliedregt and Göran Sluiter for their many helpful comments on earlier drafts of this article. Any mistakes are the author's own.

${ }^{1}$ See C. Krauss and D. Kirkpatrick, 'Libyan Fighters Catch Qaddafi's Last Fugitive Son' New York Times (New York, 19 November 2011) < http://www.nytimes.com/2011/ $11 / 20 /$ world/africa/gaddafi-son-captured-seif-al-islam-qaddafi-libya.html?pagewanted $=$ all $>$ accessed 24 January 2012. The International Criminal Court also issued an arrest warrant for former intelligence chief Abdullah al-Senussi. Al-Senussi was arrested at 
after Saif al-Islam's capture and detention in Zintan provence, the interim government in Triploi announced its intention to prosecute him domestically instead of surrendering him to the International Criminal Court (ICC). ${ }^{2}$ Despite several attempts by Libya to have the Court's Surrender Request of 5 July 2011 postponed, the arrest warrant issued by the ICC's Pre-Trial Chamber I (PTC I) on 27 June 2011 remains in effect. $^{3}$ On 1 May 2012, Libya's government formally challenged the case's admissibility pursuant to Article 19 of the Rome Statute, asking the Court to declare Saif al-Islam's case inadmissible and to quash the Surrender Request. ${ }^{4}$ The PTC is yet to render a decision on Libya's Article 19 application. So far, however, the Office of the Prosecutor (OTP) seems to favor allowing Libya a chance to pursue Saif al-Islam's case in accordance with the general rationale behind the Court's complementary position vis-à-vis national jurisdictions.

The complementarity principle in the Rome Statute of the ICC, one of the cornerstones on which today's international criminal justice is built, regulates the theoretical and practical division of labor between the Court and domestic jurisdictions. While the United

Footnote 1 continued

Nouakchott airport in Mauritania on 17 March 2012 proving the numerous previous reports of al-Senussi's capture in Libya false. According to Libyan Deputy Prime Minister Mustafa Abu Shagour (via Twitter), Mauritania already agreed to the extradition of al-Senussi to Libya. However, there are no official, independent sources to corroborate this assertion. At the time of writing, it is therefore uncertain whether al-Senussi is still in Mauritania and whether he will be extradited to Libya, to France (where al-Senussi has been sentenced in absentia to life imprisonment for a 1989 airplane bombing), or surrendered to the ICC. See L. Prieur and H. al Shachi, 'Mauritania agrees to Senussi extradition, Libya says' Reuters (New York, 20 March 2012) < http://www.reuters.com/article/2012/03/20/us-libya-senussi-idUSBRE82J0X $120120320>$ accessed 8 April 2012; Prosecutor v. Saif Al-Islam Gaddafi and Abdullah Al-Senussi (Application on behalf of the Government of Libya pursuant to Article 19 of the ICC Statute) ICC-01/11-01/11 (1 May 2012), para. 30. Given the ambiguity surrounding al-Senussi's whereabouts, this article only focuses on Saif al-Islam Gaddafi.

${ }^{2}$ See M. Simons, 'Hague Prosecutor Opens Door to Libya Trial of Qaddafi Son and Aide' New York Times (New York, 22 November 2011) < http://www.nytimes. com/2011/11/23/world/africa/hague-official-backs-trials-in-libya-for-two-men.html? $\mathrm{scp}=8 \& \mathrm{sq}=$ Seif $\%$ 20al-Islam\%20el-Qaddafi\&st $=$ cse $>$ accessed 24 January 2012.

${ }^{3}$ See Prosecutor v. Saif Al-Islam Gaddafi and Abdullah Al-Senussi (Decision Regarding the Second Request by the Government of Libya for Postponement of the Surrender of Saif Al-Islam Gaddafi) ICC-01/11-01/11 (4 April 2012), para. 19.

${ }^{4}$ See Prosecutor v. Saif Al-Islam Gaddafi and Abdullah Al-Senussi (Application on behalf of the Government of Libya pursuant to Article 19 of the ICC Statute) ICC01/11-01/11 (1 May 2012), para. 108. 
Nations ad hoc Tribunals have precedence over national jurisdictions, the ICC will only exercise jurisdiction when a state is inactive or "unwilling or unable genuinely to carry out the investigation or prosecution" of alleged perpetrators of core international crimes such as war crimes, crimes against humanity and genocide. ${ }^{5}$ The ICC is complementary to its domestic counterparts, creating a relationship of vertical influence and guidance with respect to national criminal law systems.

Saif al-Islam Gaddafi's capture, in combination with the ICC's arrest warrant, Libya's plan to try him domestically and a deferential ICC Prosecutor, raise a number of interesting procedural questions that go beyond the confines of Saif al-Islam's particular case. ${ }^{6}$ This

\footnotetext{
${ }^{5}$ See Rome Statute of the International Criminal Court, (2002) 2187 UNTS 90, Article 17 [hereinafter Rome Statute].
}

${ }^{6}$ For recent discussions among legal scholars on a number of concerns raised by Saif al-Islam Gaddafi's case (including the relationship between the ICC, Libya and the United Nations Security Council, the current status and effect of the ICC arrest warrant, the question whether Saif al-Islam ought to be surrendered to the ICC, and the consequences of an Article 19 admissibility challenge in light of Article 95 of the Rome Statute), see the following postings of Jens David Ohlin to his blog LieberCode: 'Libya \& Positive Complementarity' (21 November 2011) < http://www.lieber code.org/2011/11/libya-positive-complementarity.html > ; 'Libya's Duty to Cooperate with the ICC' (23 November 2011) < http://www.liebercode.org/2011/11/libyasduty-to-cooperate-with-icc.html >; 'Libya \& The Death Penalty: Can the ICC Complain About Too Much Punishment?' (28 November 2011) < http://www. liebercode.org/2011/11/libya-death-penalty-can-icc-complain.html > all accessed 20 January 2012. See also the following postings of Kevin Jon Heller to the blog Opinio Juris: 'Does Libya Have to Surrender Saif to the ICC? (Answer: Yes)' (23 November 2011) < http://opiniojuris.org/2011/11/23/does-libya-have-to-surrender-saif-to-theicc-answer-yes/>; 'Four Quick Thoughts on Justice in Libya' (3 January 2012) <http://opiniojuris.org/2012/01/03/four-quick-thoughts-on-justice-in-libya/ > ; 'ICC Ducks the Article 95 Issue Regarding Gaddafi' (5 April 2012) <http://opiniojuris. org/2012/04/05/icc-ducks-the-article-95-issue-regarding-gaddafi/ $>$ all accessed 11 April 2012. And see the following postings of Dapo Akande to the blog EJIL:Talk!: 'Is Libya Under an Obligation to Surrender Saif Gaddafi to the ICC? Part I (What Does the Rome Statute Say?)' (26 November 2011) < http://www.ejiltalk.org/islibya-under-an-obligation-to-surrender-saif-gaddafi-to-the-icc-part-i-what-does-therome-statute-say/ >; 'Is Libya Under an Obligation to Surrender Saif Gaddafi to the ICC? (Part II) Has the UN Security Council Imposed Different Obligations of Cooperation from the Rome Statute?' (29 November 2011) < http://www.ejiltalk. org/is-libya-under-an-obligation-to-surrender-saif-gaddafi-to-the-icc-part-ii-has-theun-security-council-imposed-different-obligations-of-cooperation-from-the-romestatute/ > ; 'Libya's Obligation to Surrender Saif Gaddafi to the ICC: A Follow Up' (20 February 2012) < http://www.ejiltalk.org/libyas-obligation-to-surrender-saifgaddafi-to-the-icc-a-follow-up/> all accessed 11 April 2012. 
article focuses only on one case-specific concern, whether Saif al-Islam will receive a fair trial in Libya, and one general question of greater importance: does the ICC's complementarity regime influence domestic due process issues?

Although many states have adopted new substantive criminal laws under the influence of the ICC's complementarity regime, the scope of the Court's authoritative guidance is disputed with respect to procedural matters, most notably due process protections. On the one hand, many scholars believe that the ICC's effect on this area of domestic criminal procedure is positive. The complementarity principle dictates regard to principles and norms of due process as recognized by international law when the Court makes an admissibility assessment under either Article 17 or Article 20(3) of the Rome Statute. Kevin Jon Heller calls this the "due process thesis". ${ }^{7}$ On the other hand, it has been argued that such an effect is beyond the Rome Statute's text, as well as beyond the drafters' intentions.

This article scrutinizes critiques of the due process thesis by assessing whether there is a legal basis for the Court's influence through an analysis of the admissibility grounds of Article 17 and Article 20(3). It touches upon those aspects of the complementarity principle that seem to affect fair trial rights at the domestic level, such as two of the Rome Statute's due process clauses: Article 17's reference to "principles of due process as recognized by international law" and Article 20(3)'s mention of "the norms of due process recognized by international law". The article suggests there is room for a moderate form of the due process thesis in case of flagrant violations of core elements of internationally recognized fair trial rights. The importance of rethinking the due process thesis is shown by Saif al-Islam's case, the fair trial concerns that have been raised in relation to his case and the compelling goal "to prevent a post-conflict free fall into vengeance, vendetta, or victor's justice". 8

In order to test the potential effect of the moderate due process thesis, this article next examines that area of law where fairness in procedure comes closest to fairness in outcome: evidentiary rules. The

\footnotetext{
${ }^{7}$ See K. Heller, 'The Shadow Side of Complementarity: The Effect of Article 17 of the Rome Statute on National Due Process' (2006) 17 Criminal Law Forum 255, 255.

${ }^{8}$ R. Teitel, 'The ICC and Saif: After International Intervention, Avoiding Victor's Justice' (Opinio Juris, 2 January 2012) < http://opiniojuris.org/2012/01/02/the-iccand-saif-after-international-intervention-avoiding-victor $\%$ E2\% $\% 0 \% 99$ s-justice $/>$ accessed 17 January 2012.
} 
rationale for choosing this field of law as a test area is twofold. First, most evidentiary rules can be construed as a form of due process protection, making it a comprehensive area of law most suitable for the purpose of this article. Second, evidentiary issues are currently under severe criticism in debates regarding international criminal fact-finding, rendering them among the most contentious topics in any due process discussion relating to the prosecution of international crimes. Moreover, fact-finding and evidentiary problems faced by the ICC may in turn affect the standards of quality that the Court can demand from domestic jurisdictions.

Thus, this article does not profess to present an exhaustive list of all areas of domestic due process rights that the moderate due process thesis may influence. Rather, the article aims at, first, introducing the moderate due process thesis, and second, placing it in a more tangible context by exploring an exemplary field of law that the suggested narrower interpretation of the classic due process thesis may affect in the future.

\section{COMPLEMENTARITY AND PRINCIPLES OF DUE PROCESS}

Article 17 of the Rome Statute dictates that the ICC does not come into play unless a state is either "unwilling" or "unable" to genuinely prosecute and punish international crimes committed within its jurisdiction. ${ }^{9}$ Consequently, if a state tries to shield the person(s) responsible for mass atrocities by undertaking sham prosecutions designed to acquit, the ICC may step in and take over the proceedings. Article 20(3) contains a similar ground for admissibility when national proceedings have already been concluded. ${ }^{10}$ The pro-

\footnotetext{
${ }^{9}$ See Rome Statute (n.5) Article 17(1)(a), which reads: "Having regard to paragraph 10 of the Preamble and article 1, the Court shall determine that a case is inadmissible where:(a) The case is being investigated or prosecuted by a State which has jurisdiction over it, unless the State is unwilling or unable genuinely to carry out the investigation or prosecution".

${ }^{10}$ Ibid. Article 20(3), which reads: "No person who has been tried by another court for conduct also proscribed under article 6,7 or 8 shall be tried by the Court with respect to the same conduct unless the proceedings in the other court:(a) Were for the purpose of shielding the person concerned from criminal responsibility for crimes within the jurisdiction of the Court; or(b) Otherwise were not conducted independently or impartially in accordance with the norms of due process recognized by international law and were conducted in a manner which, in the circumstances, was inconsistent with an intent to bring the person concerned to justice".
} 
vision's "upward" principle of ne bis in idem vis-à-vis the ICC does not apply when proceedings in a national court were intended to shield the person concerned from criminal responsibility or were otherwise conducted improperly. ${ }^{11}$

Both provisions form exceptions to the general rule that the ICC is barred from exercising jurisdiction where national justice systems are engaged. However, the question remains to what extent this exception results in the Rome Statute demanding procedural reform at the national level, and whether not providing a defendant with basic due process rights constitutes inability or unwillingness to prosecute offenders, or alternatively, makes a case admissible under Article 20(3). ${ }^{12}$ The due process thesis answers the latter question in the affirmative, but in its current form, the thesis has not gone without criticism.

\subsection{The Due Process Thesis: The Treaty and Critiques}

The ICC may be viewed as a role model of due process, as it gives defendants all the procedural rights enumerated in the International Covenant on Civil and Political Rights (ICCPR).${ }^{13}$ Moreover, Article 17 of the Rome Statute, most clearly giving effect to the complementarity principle, refers to "the principles of due process recognized by international law" in its second paragraph. This seems to underline the assumption that the ICC has a positive effect on national due process rights. As noted by scholars in Triffterer's Commentary to the Rome Statute, Article 17 may even require "an assessment of the quality of justice from the standpoint of procedural and perhaps even substantive fairness". ${ }^{14}$ Arguably, a state's failure

${ }^{11}$ Ibid. Article 20(3); see also C. Van den Wyngaert and T. Ongena, 'Ne bis in idem Principle, Including the Issue of Amnesty' in A. Cassese, P. Gaeta and J.R.W.D. Jones (eds), The Rome Statute of the International Criminal Court: A Commentary, vol 1 (Oxford, Oxford University Press, 2002) 724-725.

${ }^{12}$ See for example G. S. McNeal, 'ICC Inability Determinations in Light of the Dujail Case' (2006) 39 Case Western Reserve Journal of International Law 325, 325; Heller (n. 7); J. Kleffner, Complementarity in the Rome Statute and National Criminal Jurisdictions (Oxford, Oxford University Press, 2008) 130 [hereinafter Kleffner, Complementarity].

${ }^{13}$ See Heller (n. 7) 256.

${ }^{14}$ S. A. Williams and W. A. Schabas, 'Article 17: Issues of Admissibility' in O. Triffterer (ed), Commentary on the Rome Statute of the International Criminal Court: Observers' Notes, Article by Article (Munich, Oxford, C. H. Beck, 2008) 623. 
to guarantee a defendant due process rights, most notably basic fair trial rights as recognized in international human rights law, makes a case admissible under Article 17.

Heller refers to this interpretation of the complementarity principle, observing that it is widely supported, ${ }^{15}$ as the "due process thesis". ${ }^{16}$ However, he counters the thesis, phrasing the most fundamental objection, by stating that "[p]roperly understood, article 17 permits the Court to find a State 'unwilling or unable' only if its legal proceedings are designed to make a defendant more difficult to convict. If its legal proceedings are designed to make the defendant easier to convict, the provision requires the Court to defer to the State no matter how unfair those proceedings may be". ${ }^{17}$

Article 17's admissibility assessment consists of a number of elements that are necessarily scrutinized in the due process thesis debate. For instance, with respect to "inability", Heller notes that scholars generally argue that a state is "unable" in the sense of Article 17 if it does not guarantee a fair trial for the defendant. ${ }^{18}$ The Informal Expert Paper on complementarity issued by the ICC's OTP supports this stance. ${ }^{19}$ However, Heller argues that this is an unrealistic interpretation of "inability". The third paragraph of Article 17 elaborates on what constitutes an inability to investigate or prosecute, stating that the Court should consider whether "due to a total or substantial collapse or unavailability of its national judicial system, the State is unable to obtain the accused or the necessary evi-

\footnotetext{
${ }^{15}$ See Heller (n. 7) 256; see also M. S. Ellis, 'The International Criminal Court and Its Implication for Domestic Law' (2002) 15 Florida Journal International Law 215, 221-222; J. Kleffner, 'The Impact of Complementarity on National Implementation of Substantive International Criminal Law' (2003) 1 Journal of International Criminal Justice 86, 105-106 [hereinafter Kleffner, Substantive]; C. Stahn, 'Complementarity, Amnesties, and Alternative Forms of Justice; Some Interpretative Guidelines for the International Criminal Court' (2005) 3 Journal of International Criminal Justice 695, 713; C. Stahn, 'Complementarity: A Tale of Two Notions' (2008) 19 Criminal Law Forum 87, 97; C. Stahn, 'Libya, the International Criminal Court and Complementarity' (2012) 10 Journal of International Criminal Justice 325, 344-345.

${ }^{16}$ See Heller (n. 7) 257.

17 Ibid.

18 Ibid., 259.

${ }^{19}$ See International Criminal Court Office of the Prosecutor, 'An Informal Expert Paper: The Principle of Complementarity in Practice' (2003) < http://www.icc-cpi. int/iccdocs/doc/doc654724.pdf $>$ accessed 19 December 2011, 28 [hereinafter Informal Expert Paper].
} 
dence and testimony or otherwise unable to carry out its proceedings". ${ }^{20}$ On the one hand, "[i]t is difficult to argue that we would ordinarily describe a functioning national judicial system that lacks certain due process protections as one that has 'collapsed' or become "unavailable". ${ }^{21}$ One may argue that such an expansion of the ICC's jurisdiction goes beyond the intentions of the Rome Statute's drafters. $^{22}$ On the other hand, demanding complete compliance with international due process standards is not necessary. It would be realistic to regard the lack of basic due process rights for an accused as an inability in the sense of Article 17. Such a moderate way of assessing "inability" is in line with the treaty's text as it targets not any lack of due process rights but a lack of even the most basic due process protections.

The next element, part of the willingness assessment in Article 17(2)(c), provides a good argument in support of the due process thesis as it lists the requirement that national proceedings must be conducted independently and impartially. ${ }^{23}$ However, basing the due process thesis on this element has also been criticized. ${ }^{24}$ The subparagraph continues with a conjunctive requirement ("and" as opposed to "or"), namely that a national proceeding is also "being conducted in a manner which, in the circumstances, is inconsistent with the intent to bring the person concerned to justice". One may conclude that this is reason enough to assume that an unfair trial designed to convict, but still with the intent to bring the person to justice, does not constitute unwillingness on the part of a state.

However, Article 17(2)(c) leaves room for different interpretations. First, biased proceedings against a person other than the actual

${ }^{20}$ See Rome Statute (n. 5) Article 17(3).

${ }^{21}$ See Heller (n. 7) 264.

$22 \mathrm{Ibid}$; see also McNeal (n. 12) 333.

${ }^{23}$ See Rome Statute (n. 5) Article 17(2), which reads: "In order to determine unwillingness in a particular case, the Court shall consider, having regard to the principles of due process recognized by international law, whether one or more of the following exist, as applicable: (a) The proceedings were or are being undertaken or the national decision was made for the purpose of shielding the person concerned from criminal responsibility for crimes within the jurisdiction of the Court referred to in article 5; (b) There has been an unjustified delay in the proceedings which in the circumstances is inconsistent with an intent to bring the person concerned to justice; (c) The proceedings were not or are not being conducted independently or impartially, and they were or are being conducted in a manner which, in the circumstances, is inconsistent with an intent to bring the person concerned to justice".

${ }^{24}$ See Heller (n. 7) 260-261; Kleffner, Complementarity (n. 12) 130. 
perpetrator, so-called scapegoat trials meant to convict, as opposed to sham prosecutions designed to shield and acquit, are neither conducted impartially nor are they consistent with the intent to bring the person concerned (i.e. the real perpetrator) to justice. ${ }^{25}$ In comparing the historical Justice case, in which judges, prosecutors and officials of the Reich Ministry of Justice were found guilty of crimes against humanity for abusing the judicial process to further the persecution and extermination of minorities and political opponents of the Nazi regime, one can see the ultimate consequence of the strategy of systematically denying fair trial rights. ${ }^{26}$ Such a denial may lead to an assessment of unwillingness under today's ICC regime. When the "person concerned" turns out to be the real perpetrator but the trial was unfair, one could still argue that such proceedings are inconsistent with the intent to bring the individual to justice. $^{27}$

Second, it must be an extremely difficult task for the Court to determine whether a violation of due process rights took place to the benefit or the detriment of the accused. ${ }^{28}$ Consider, for example, Saif al-Islam's case. An assessment of whether or not he will benefit from due process abuses is not easily made at this point in time (in advance), and seems highly impractical.

The most promising element of Article 17 in light of the due process thesis is the subordinate clause in the chapeau of the second paragraph, to which this article refers as Article 17's due process clause: "In order to determine unwillingness in a particular case, the Court shall consider, having regard to the principles of due process recognized by international law, whether one or more of the following exist (...)". ${ }^{29}$ However, this paragraph could suffer a similar (grammatical) fate, since the article's chapeau and subparagraphs are

${ }^{25}$ See Kleffner, Substantive (n. 15) 105-106 (n. 93); see also F. Gioia, 'Comments on Chapter 3' in J. Kleffner and G. Kor (eds), Complementarity Views on Complementarity: Proceedings of the International Roundtable on the Complementary Nature of the International Criminal Court, Amsterdam 25/26 June 2004(The Hague, TMC Asser Press, 2006) 112.

${ }^{26}$ See U.S.A. v. Josef Alstotter et al. (the 'Justice case'), Trials of War Criminals Before the Nuremberg Military Tribunals Under Control Council Law No. 10 (Nuremberg, October 1946-April 1949), vol. III, at 1046-47; see also R. May and M. Wierda, International Criminal Evidence (Leiden, Martinus Nijhoff, 2002) 259.

${ }^{27}$ See Kleffner, Substantive (n. 15) 105-106 (n. 93).

${ }^{28}$ See Gioia (n. 25) 112.

${ }^{29}$ Rome Statute (n. 5) Art. 17(2) [emphasis added]. 
conjunctive as well. ${ }^{30}$ The subordinate clause merely provides guidance as to how the Court should determine whether one of the subparagraphs applies. This is not necessarily fatal to the due process thesis, though. As noted above in relation to the willingness requirement, the intent to bring the person concerned to justice may be interpreted less rigidly leaving room for the due process thesis.

In sum, the fundamental objection against the due process thesis is expressed in the conclusion that a case becomes admissible under the complementarity regime only when defendants receive too many due process rights, which serve as a cloak to shield the person concerned from justice. Consequently, if a defendant is deprived of sufficient due process rights, which amounts to an unfair trial to the detriment of the individual, the case is not admissible as long as a state has the intent to bring the person to justice. Applied to Saif al-Islam's case, the denial of the due process thesis leads to the conclusion that his case will most likely remain inadmissible since Libyan authorities have expressed nothing but eagerness to prosecute him and have shown no intentions to shield him from a conviction or to protect him from an actual sentence. The question whether Saif al-Islam will receive a fair trial would be immaterial as long as the intent to bring him to justice is present. However, while having regard for the objections to the due process thesis elaborated upon above, this conclusion can be disputed for the reasons following below.

\subsection{Introducing a Moderate Form of the Due Process Thesis}

\subsubsection{Article 17's Due Process Clause}

John T. Holmes's account of the negotiations on complementarity, which Holmes himself coordinated in Rome in 1998, is a useful tool for going beyond textual interpretation and looking into the drafting history. ${ }^{31}$ An examination of the preparatory work of the Rome Statute seems to suggest that it was not the drafters' intention to expand the scope of the ICC's jurisdiction in such a way that is reconcilable with the classic due process thesis. ${ }^{32}$ Although suggested by some delegations, many did not believe that the absence of

${ }^{30}$ See Heller (n. 7) 262-263.

${ }^{31}$ See J. T. Holmes, 'The Principle of Complementarity' in R. S. Lee (ed), The International Criminal Court: The Making of the Rome Statute: Issues, Negotiations, Results (Leiden, Kluwer Law International, 1999) 41.

${ }^{32}$ Ibid., 50; see also Heller (n. 7) 271-273. 
national due process rights should be a ground for admissibility. ${ }^{33}$ When interpreting the drafting history stringently, one may conclude together with opponents of the due process thesis that each element of the Rome Statute's complementarity principle was put in there for good, but different reasons.

However, there is one aspect of which the underlying reason for inclusion is highly unsatisfactory. The subordinate clause in Article 17(2), which refers to the principles of due process as recognized by international law, was added at the last minute in Rome as an "element of objectivity to all the criteria of unwillingness". ${ }^{34}$ Delegations worried that the ICC would be granted too much discretion in determining whether a state was "unwilling" and repeatedly expressed the concern that the provision lacked objective criteria on which the Court would base its assessment, rendering it too subjective. ${ }^{35}$

Thus, it is clear that the drafters did not want the words "due process" in Article 17(2) to mean complete compliance with international human rights standards. It is clear why the drafters of the Statute added them (to add an element of objectivity), but it is not clear what is left, if anything, of the clause's meaning in practice. Apparently, the drafters intentionally chose an ambiguous term in order to allow for an assessment on a case-by-case basis. However, it is problematic that "objectivity", a rather vague term in this context, is also stated as the underlying reason for including the word "genuinely" in Article 17. The Informal Expert Paper states that the addition "genuinely" brings "a certain basic level of objective quality". ${ }^{36}$ Both the word "genuinely" and Article 17's due process clause were added to guarantee more objectivity. The word "genuinely", due to its placement as an adverb in Article 17(1)(a), applies to both "inability" and "unwillingness". Therefore, with respect to "unwillingness", the objectivity requirement is added twice: once in the form of requiring genuineness, and once in the form of requiring a regard to the principles of due process as recognized by international law. In essence, if every form of the due process thesis is denied, and it is assumed that the reference to international due process principles is absolutely limited to meaning an added element of objectivity, then

\footnotetext{
${ }^{33}$ See Holmes (n. 31) 50; see also Heller (n. 7) 272.

${ }^{34}$ Holmes (n. 31) 54.

35 Ibid., 53; see also Kleffner, Complementarity (n. 12) 90.

${ }^{36}$ Informal Expert Paper (n. 19) 8.
} 
the subordinate clause in Article 17(2) is obsolete. Article 17(1)(a) already demands objectivity.

Although hardly unprecedented and perhaps even understandable in light of the undoubtedly exhausting drafting circumstances, it is at least problematic that the Rome Statute includes such grand words merely to have them serve as an unnecessary safeguard. Moreover, as will be discussed below, such an interpretation of the Statute's due process clauses is not in keeping with the general objective and meaning of due process rights.

\subsubsection{Due Process Rights: Objective and Scope}

The conclusion that Article 17(2) is only written for the situation in which criminal processes are abused to the benefit of the suspect or accused reveals a dichotomy. As Jann Kleffner states: "[t]his [conclusion] is diametrically opposed to the general assumption and objective of fair trial guarantees, which are designed to protect individuals against abuses to their disadvantage". ${ }^{37}$ Although not subscribing to the due process thesis, Kleffner hits the nail on the head, since the concept "due process of law" emerged as regulating legal proceedings in accordance with rules and principles which safeguard the position of the individual charged. ${ }^{38}$ It is a universally accepted principle of international law that trials must be fair. ${ }^{39}$ Therefore, interpreting Article $17^{\prime}$ s due process clause as only intended to prevent abuse of the criminal process to the advantage of the accused is a contradiction in terms. It is diametrically opposed to the general assumption and objective of fair trial guarantees, which are designed to protect individuals against abuses to their disadvantage, namely arbitrariness.

Due process and fair trial rights do not have a fixed meaning in any legal system, but they generally refer to the idea that citizens have fundamental rights vis-à-vis the state or the government to delimit the latter's power. ${ }^{40}$ In other words, these types of rights are designed to

\footnotetext{
${ }^{37}$ Kleffner, Complementarity (n. 12) 130.

38 Ibid., 129.

${ }^{39}$ See A. Cassese, International Criminal Law (Oxford, Oxford University Press, 2nd edn., 2008) 383.

${ }^{40}$ See A. Duff et al., 'Introduction: Towards a Normative Theory of the Criminal Trial' in A. Duff et al. (eds), The Trial on Trial: Truth and Due Process, vol 1 (Oxford, Hart Publishing, 2004) 24; See also Taxquet v. Belgium App no 926/05 (ECtHR, 31 January 2009); Joint Anti-Fascist Refugee Committee v. McGrath, 341 U.S. 123 (1951) 162-163.
} 
(a) protect the individual from a greater power, namely the government or the state, and more specifically, (b) prevent arbitrary abuse of that power. As noted above, the Informal Expert Paper states that the word "genuinely" brings a certain basic level of objective quality. ${ }^{41}$ The Paper continues that although human rights standards may still be relevant for assessing whether national proceedings are carried out genuinely, the ICC is not a human rights court, nor is its role to demand perfect compliance with international human rights standards. ${ }^{42}$ According to the authors of the Informal Expert Paper, this does not mean that human rights standards play no role at all, since "(...) human rights standards may still be of relevance and utility in assessing whether the proceedings are carried out genuinely". ${ }^{43}$

Taking internationally recognized fair trial principles into account does not mean that the ICC would turn into a human rights court (an often stated counterargument). The drafters did not intend the Court to be the type of human rights body we know from international human rights law, but this does not mean human rights will not play a role. Domestic fair trial rights are a valid concern, as shown by Saif al-Islam's case, and said counterargument should not paralyze the complementarity debate. Furthermore, a certain role for human rights within the complementarity framework is in line with the Rome Statute's Article 21, which states that the application and interpretation of law by the Court must be consistent with internationally recognized human rights.

\subsubsection{A Process-Oriented Approach}

Interpreting Article 17 to make cases admissible only where the criminal process is being abused to the benefit of the accused, suggests that the Court's unwillingness assessment is one focusing on result, not process. The inclusion of the phrase "with an intent to bring the person concerned to justice" makes this suggestion reasonable, as it seems to imply that a result that shields the person concerned from justice would be impermissible. ${ }^{44}$ However, as stipulated before, biased proceedings against persons other than the

${ }^{41}$ See Informal Expert Paper (n. 19) 8.

42 Ibid., 8-9.

${ }^{43}$ Ibid.

${ }^{44}$ See L. Waldorf, "“A Mere Pretense of Justice": Complementarity, Sham Trials, and Victor's Justice at the Rwanda Tribunal' (2010) 33 Fordham International Law Journal 1221, 1266. 
actual perpetrator are not consistent with the intent to bring the person concerned, i.e., the real perpetrator, to justice either. ${ }^{45}$

Moreover, although the language of the Rome Statute is slightly ambiguous on this matter, Article 17 clearly refers to "proceedings" as opposed to any type of result, such as a final verdict or sentence. The authors of the Informal Expert Paper confirm that the assessment required by Article 17 "should be based on procedural and institutional factors, not the substantive outcome", ${ }^{46}$ which suggests a more objective assessment consistent with the due process thesis.

In this context, "the intent to bring to justice" may be defined as striving to assure that the actual perpetrator is arrested and tried in court. ${ }^{47}$ Heller declares "justice" synonymous with conviction, but reads into the word, as it is used in Article 17, the successful conclusion of criminal proceedings against the actual perpetrator. "Justice" per se can mean conviction in some instances. For example, the Oxford English Dictionary defines justice as alternatively, infliction of punishment, legal vengeance on an offender, capital punishment or execution. ${ }^{48}$ But a different and broader definition applies here. ${ }^{49}$ Indeed, defining the intent to bring to justice as "to do someone justice" stretches beyond the limits of Article $17 .{ }^{50}$ However, jumping ahead and defining it as synonymous with conviction incorrectly labels the unwillingness assessment as one of result. In Article 17, the focus is on the proceedings. Therefore, the meaning of justice ought to be understood as prosecuting a person by arresting him and trying him in court.

A criminal process designed to acquit, where an abundance of due process rights serves as a cloak that shields the person concerned from justice, may be difficult to prove. ${ }^{51}$ However, so may a scape-

\footnotetext{
${ }^{45}$ Supra Section 2.1.

${ }^{46}$ Informal Expert Paper (n. 19) 14. law or a judicial proceeding.

${ }^{48}$ See Oxford English Dictionary (n. 47).

${ }^{49}$ See Scharf (n. 47) 525.

${ }^{50}$ See Kleffner, Complementarity (n. 12) 152.

${ }^{51}$ See Waldorf (n. 44) 1266.
}

${ }^{47}$ See Oxford English Dictionary (2nd edn, Oxford, Oxford University Press, 1989; online version June 2011); see also Kleffner, Complementarity (n. 12) 151-152; M. Scharf, 'The Amnesty Exception to the Jurisdiction of the International Criminal Court' (1999) 32 Cornell International Law Journal 507, 525; cf. Heller (n. 7) 261-262, assuming that the intent to bring to justice is synonymous with the intent to obtain a conviction, instead of defining justice as submitting a person to the administration of 
goat trial designed to convict. The Informal Expert Paper addresses these difficulties by providing a list of factors that may be indicative of a non-genuine use of proceedings, which includes a regard for fair trial rights. ${ }^{52}$ For instance, one of the items mentioned by the Informal Expert Paper is the "[l]egal regime of due process standards, rights of the accused, [and] procedures". 53 If the admissibility assessment were one of result, it would entail the Court making a (preliminary) guilt-innocence assessment beyond the scope of the complementarity principle. ${ }^{54}$ One scholar rightly notes in this respect that the Court's Prosecutor, who is the first on the ground to make an initial assessment of local regimes in light of the complementarity principle, has an obligation pursuant to Article 54(1)(a) of the Rome Statute "[i]n order to establish the truth, extend the investigation to cover all facts and evidence relevant to an assessment of whether there is criminal responsibility under this Statute, and, in doing so, [to] investigate incriminating and exonerating circumstances equally". 55

Objectifying the unwillingness assessment by making it one of procedure makes sense for a more practical reason as well. As stipulated above when discussing the meaning of "the person concerned", 56 it would be very difficult for the Court acting under Article 17 "to determine ex ante whether a violation of the principles of due process occurred to the detriment or to the benefit of the accused". 57

One may argue that the denial of the due process thesis results in an assumption of guilt. Again, consider Saif al-Islam's case. Will the ICC not step in unless Libya is suspected of providing Saif al-Islam with an abundance of due process protections that prevent a genuine prosecution and conviction? Regardless of the unattractive message that would send to the world, in this scenario Saif al-Islam would (already) be assumed a guilty person benefitting from a sham prosecution. However, the main reason for including the due process clause and the word "genuinely" in Article 17 of the Rome Statute was to add a certain amount of objectivity to the admissibility assessment. In essence, the presumption of innocence is the right that

\footnotetext{
${ }^{52}$ See Informal Expert Paper (n. 19) 28-31.

53 Ibid., 28.

${ }^{54}$ See Gioia (n. 25) 112.

55 Ibid.

56 Supra Section 2.1.

${ }^{57}$ See Gioia (n. 25) 112.
} 
most objectifies the criminal process, and therefore, it comes to mind as one of the due process rights recognized by international law that the Court must take into account. Given that Article 17 requires a process-oriented approach, as opposed to a result-oriented approach, the presumption of innocence seems to play a role here as an additional confirmation that the Court's assessment must be objective. If the person concerned is not presumed innocent, or even assumed guilty, an internationally recognized principle of due process is not being taken into account. Such a system moves closer to Herbert Packer's well-known Crime Control Model, in which the presumption of guilt "is basically a prediction of outcome". 58

It has been rightly suggested that "a trial falling short of international standards of fairness [is] contrary to the very purpose of holding international trials". ${ }^{59}$ More appropriate for a model court as ambitious as the ICC is a system resembling Packer's Due Process Model, even in preliminary assessments like that which Article 17 demands. Such a model is supported by not only the very objectives pursued by creating the ICC but also, as the analysis of Article 17 and its due process clause shows, the text of the Rome Statute itself.

\subsubsection{Article 20's Due Process Clause}

After the due process clause had been accepted relatively easily regarding Article 17(2), the drafters believed it should also be included in Article 20(3) in order to secure the same type of objectivity when the Court considers deviation from the ne bis in idem principle. ${ }^{60}$ However, oddly enough, the words were not precisely duplicated. The due process clause in Article 20(3) reads, "in accordance with the norms of due process recognized by international law" as opposed to the principles of due process as it is phrased in Article 17. Nevertheless, there is no indication that the due process clause in Article 20(3) should be read or interpreted differently than the clause as found in Article 17(2). Delegations were satisfied to borrow strongly from the compromise already achieved on Article 17, since ne bis in idem is part of the complementarity principle. A reference to it is in fact incorporated in Article 17(1)(c). ${ }^{61}$ Moreover, the rest of the provision's language is almost identical to Article 17's wording,

\footnotetext{
${ }^{58}$ H. L. Packer, 'Two Models of the Criminal Process' (1964) 113 University of Pennsylvania Law Review 1, 12.

${ }^{59}$ May and Wierda (n. 26) 260.

${ }^{60}$ See Holmes (n. 31) 59.

${ }^{61}$ Ibid., 58.
} 
which made it widely acceptable for inclusion in Article 20(3). ${ }^{62}$ It is, therefore, reasonable to assume that the rationale behind both due process clauses is the same, despite fairly careless drafting.

Still, the inclusion of (approximately) the same phrase in Article 20(3) may seem slightly puzzling to some. Commentators noted the striking difference from the ne bis in idem principle as incorporated in the Statute of the Yugoslavia Tribunal. ${ }^{63}$ The latter only refers to national proceedings that were not independent and impartial and were intended to shield the accused from justice, while the Rome Statute's ne bis in idem principle also refers to the norms of due process as recognized by international law. Given the drafter's intentions in including a due process clause in Article 17 and the wide consensus among them to copy the phrase into Article 20, we must assume that the deviation from the Yugoslavia Tribunal's Statute was an intentional one. Therefore, the ICC's assessment under Article 20(3) can go in both directions: against or in favor of the accused. ${ }^{64}$ From the point of view of chronological continuity this makes sense. Once domestic proceedings have come to an end, Article 17 is no longer applicable. However, the Rome Statute's drafters wished for the same safeguards to apply at this later stage. ${ }^{65}$

Article 20(3) also clearly refers to "proceedings". Although the Informal Expert Paper on complementarity does not cover Article 20, it is reasonable to assume that, in light of the similarities between Article 17 and Article 20(3), the provision demands a similarly objective assessment focused on the process, not the substantive outcome. At first blush, this may seem less logical in relation to the ne bis in idem principle. However, if the Court could only look at the substantive outcome, and not the proceedings as a whole, states would essentially be more likely to be in the clear once proceedings

${ }^{62}$ See Rome Statute (n. 5) Article 20(3), which reads: "No person who has been tried by another court for conduct also proscribed under article 6,7 or 8 shall be tried by the Court with respect to the same conduct unless the proceedings in the other court:(a) Were for the purpose of shielding the person concerned from criminal responsibility for crimes within the jurisdiction of the Court; or(b) Otherwise were not conducted independently or impartially in accordance with the norms of due process recognized by international law and were conducted in a manner which, in the circumstances, was inconsistent with an intent to bring the person concerned to justice".

${ }^{63}$ See Van den Wyngaert and Ongena (n. 11) 725.

${ }^{64}$ See I. Tallgren and A. R. Coracini, Article 20: Ne bis in idem, in Triffterer (n. 14), 694-695.

${ }^{65}$ See Holmes (n. 31) 59. 
are concluded. They would have too much freedom in setting up sham and show proceedings, as long as they speed things along, if the Court lacks the actual competence to adequately step in at all stages of national proceedings (Kompetenz Kompetenz). ${ }^{66}$

\subsubsection{The Moderate Due Process Thesis: Which Rights?}

It has already been mentioned that while demanding complete compliance with all fair trial rights recognized by international law is unrealistic, it is viable to demand adherence to basic due process rights ${ }^{67}$ This is where the moderate due process thesis deviates from the classic due process thesis. The Rome Statute's principle of complementarity allows for such a reduced form of the due process thesis, but the Statute does not identify which due process rights Article 17 and 20(3) refer to. However, as the norms and principles of due process need to be recognized by international law, the most logical place to find these rights is in international human rights treaties.

In order to establish which of these internationally-found rights are basic fair trial rights, we may look at the underlying idea of a fair trial or due process, which is captured in the belief that not only does a citizen need protection from the state, but also that there is some kind of "inner morality" to criminal proceedings. ${ }^{68}$ There are six core elements to this idea of a fair trial, which have been usefully summarized by Mireille Hildebrandt using international documents such as the European Convention on Human Rights ${ }^{69}$ : (1) the judge is impartial and independent; (2) the trial is public; (3) the defendant will not be punished without a legal finding of guilt (the presumption of innocence); (4) there is an equality of arms between prosecution and defense; (5) the judgment will be based on evidence presented in court (a principle of immediacy, connected with a normative preference for oral testimony); and (6) the proceedings are based on a right of confrontation. ${ }^{70}$ Jens David Ohlin provides a similar inventory containing "a basic level of due process [rights] universally recognized

\footnotetext{
${ }^{66}$ See Van den Wyngaert and Ongena (n. 11) 724-725.

${ }^{67}$ Supra Section 2.1.

${ }^{68}$ See A. Duff et al., The Trial on Trial: Towards a Normative Theory of a Criminal Trial, vol 3 (Oxford, Hart Publishing, 2007) 51.

${ }^{69}$ See M. Hildebrandt, 'Trial and 'Fair Trial': From Peer to Subject to Citizen' in A. Duff et al. (eds), The Trial on Trial: Judgment and Calling to Account, vol 2 (Oxford, Hart Publishing, 2006) 25; see also Duff et al. (n. 68) 51.

${ }^{70}$ See European Convention for the Protection of Human Rights and Individual Freedoms, (1950) 213 U.N.T.S. 221, Article 6.
} 
among civilized nations," Civil and Political Rights. ${ }^{72}$

It must be noted that the idea of a fair trial has been further internationalized with the realization of the international criminal tribunals and the permanent ICC. At these courts, "the dominant idea is perhaps less that of the individual protection than that the international community should be seen to be acting according to demonstrable principles of fairness". ${ }^{73}$ This underscores that the ICC, as a role model of due process, ${ }^{74}$ should extend its influence to national due process rights where the abovementioned basic rights are not granted.

Whether domestic authorities grant basic due process rights will need to be assessed on a case-by-case basis. The six core elements summarized by Hildebrandt provide an excellent starting point for assessing whether national justice is failing or has failed dramatically. Based on a realistic execution of the moderate due process thesis, only gross violations of the six core elements of basic due process rights would make a case admissible under the ICC's complementarity regime. Part III will address such assessments in more detail.

\subsubsection{Practice: Moving Towards the Moderate Due Process Thesis}

Despite skepticism of the due process thesis and concerns for its impracticality, neither the ICC nor the individual states seem to express adherence to some form of due process thesis as a burden; they are generally willing to subscribe to it. ${ }^{75}$

${ }^{71}$ J.D. Ohlin, 'A Meta-Theory of International Criminal Procedure:Vindicating the Rule of Law', (2009) UCLA Journal of International Law and Foreign Affairs 77, 93 n. 75.

${ }^{72}$ See International Covenant on Civil and Political Rights, (1966) 999 UNTS 171, Article 14.

${ }^{73}$ See Duff et al. (n. 68) 51.

${ }^{74}$ See Heller (n. 7) 256.

${ }^{75}$ See McNeal (n. 12) 332; see also M. Delmas-Marty, 'Interactions Between National and International Criminal Law in the Preliminary Phase of Trial at the ICC', (2006) 4 Journal of International Criminal Justice 2, 5-6, citing International Criminal Court Office of the Prosecutor, 'Paper on some Policy Issues' (4 September 2003), <http://www.icc-cpi.int/NR/rdonlyres/1FA7C4C6-DE5F-42B7-8B25-60AA 962ED8B6/143594/030905_Policy_Paper.pdf > accessed 21 December 2011. 
In relation to the ICC, Gregory McNeal notes the Court's migration towards the due process thesis is illustrated by the Report of the Commission of Inquiry on Darfur. ${ }^{76}$ The Commission investigated whether Sudan was unwilling and/or unable to prosecute the alleged perpetrators of the atrocities committed in Darfur. The Report lists six reasons for referring the situation in Darfur to the ICC, including "the fair trial guarantees offered by the international composition of the Court and by its rules of procedure and evidence", ${ }^{77}$ indeed suggesting a migration towards the due process thesis.

Not only the ICC, but also states are moving towards a due process thesis approach. As shown by Kenya's application, the first of its kind, to the ICC's Pre-Trial Chamber II under Article 19 of the Rome Statute in March 2011, states assume that strengthening fair trial rights and procedural guarantees are indeed amongst their obligations under the Rome Statute. ${ }^{78}$ In the application's second paragraph, the government of Kenya starts its list of reforms by pointing out that "[t]he new Constitution incorporates a Bill of Rights which significantly strengthens fair trial rights and procedural guarantees within the Kenyan criminal justice system". ${ }^{79}$ The Libyan authorities seem to move in this direction as well. Not only have they repeatedly made similar statements in relation to Saif al-Islam's fate, assuring that Gaddafi's son will receive a fair trial, ${ }^{80}$ their recent Article 19 application devotes over 10 paragraphs to defending the quantity and the quality of due process protections in Libya's criminal proceedings. ${ }^{81}$ The Libyan government naturally does not con-

${ }^{76}$ See McNeal (n. 12) 332; Delmas-Marty (n. 75) 5-6, citing 'Report of the International Commission of Inquiry on Darfur to the United Nations' (UN Doc. S/2005/60, 25 January 2005), para. 648.

77 'Report of the International Commission of Inquiry on Darfur to the United Nations' (UN Doc. S/2005/60, 25 January 2005), para. 648.

${ }^{78}$ See Prosecutor v. Ruto et al and Prosecutor v. Muthaura et al (Application on behalf of the Government of the Republic of Kenya Pursuant to Article 19 of the ICC Statute) ICC-01/09-01/11-19 (31 March 2011), para. 2.

${ }^{79}$ Ibid.

${ }^{80}$ See e.g., 'Libya pledges 'fair trial' for Saif al-Islam' Al Jazeera (Doa, 20 November 2011) <http://www.aljazeera.com/news/africa/2011/11/2011112052 915845986.html > accessed 3 March 2012; 'Libya: Gaddafi son Saif al-Islam "will get fair trial"” $B B C$ (London, 20 November 2011) < http://www.bbc.co.uk/news/ world-africa-15810142> accessed 3 March 2012.

${ }^{81}$ See Prosecutor v. Saif Al-Islam Gaddafi and Abdullah Al Senussi (Application on Behalf of the Government of Libya purusant to Article of the ICC Statute) (n. 4), paras. 56-67. 
firm the due process thesis while it understandably does not make the uncongenial argument of denying the thesis either. But it (perhaps unintentionally) articulates a moderate form of the due process thesis: "[i]t is not the function of the ICC to hold Libya's national legal system against an exacting and elaborate standard beyond that basically required for a fair trial". ${ }^{82}$

\section{THE MODERATE DUE PROCESS THESIS IN CONTEXT: EVIDENTIARY RULES}

The moderate due process thesis entails the ICC approaching situations objectively (refraining from any preliminary guilt/innocenceassessments), focusing on the proceedings, and determining whether one of the six core fair trial elements has been so grossly violated that it warrants a case's admissibility. In Saif al-Islam Gaddafi's case, the following questions may be asked: has the accused already been brought before an impartial and independent judge? Does he have access to counsel and other recourses, and has he been informed of the charges against him to allow an equal opportunity to prepare his defense? Will his trial be public, and will he get the opportunity to examine witnesses against him?

These questions show that the moderate due process thesis would have an effect on certain aspects of domestic evidence law, as evidentiary rules comprise a fair amount of the six core elements of a fair trial discussed above. ${ }^{83}$ This section explores how due process rights are related to evidentiary rules, placing the moderate due process thesis in a more concrete context. Certain practical issues cannot be ignored here. The search for the truth, which is intimately connected to both due process rights and evidentiary rules, is an area currently heavily under debate in relation to international crime prosecutions. Today's international criminal tribunals experience many evidentiary difficulties in the form of fact-finding impediments. These challenges may be relevant as a correctional factor to the Court's admissibility assessment in cases of substandard due process protections.

\footnotetext{
${ }^{82}$ Ibid., 99 [emphasis added].

${ }^{83}$ Supra Section 2.2.5.
} 


\subsection{Evidentiary Rules as Due Process Protections}

Evidence may be defined as relevant, i.e. material and probative, information put before a court to establish a fact in question. ${ }^{84}$ Evidentiary rules identify and govern how this information is used at trial. ${ }^{85}$ Obviously, a judgment must be fact-based to be fair. As a tool for accurate fact-finding, evidentiary rules guarantee procedural fairness through identifying and governing the information presented at trial. In other words, "[e]vidence is that area of criminal justice which comes closest to linking fairness in procedure with fairness in outcome". ${ }^{86}$

Fair trial rights prevent miscarriages of justice and set boundaries on truth-finding. ${ }^{87}$ These boundaries do not necessarily stand in the way of the search for the truth: "(...) while effective prosecutions without too many barriers caused by principles of due process may lead to more convictions (...) they may not lead to accurate results". ${ }^{88}$ One may argue that respecting individual rights even contributes to truth-finding. Due process rights comprise the structural protection that is designed to produce the correct outcomes and to make the correct culpability determinations. ${ }^{89}$ Accordingly, due process rights have a direct effect on the search for the truth, as they are designed to ensure that the prosecution does not have an unfair advantage and taint the outcome of the trial, potentially causing the innocent to be convicted..$^{90}$

The rules created to ensure procedural fairness directly affect criminal proceedings with respect to the admission and consideration of evidence. ${ }^{91}$ Evidence and due process are intimately connected in

${ }^{84}$ See May and Wierda (n. 26) 2; see also M. C. Bassiouni, 'Issues Pertaining to the Evidentiary Part of International Criminal Law' in M. C. Bassiouni (ed), International Criminal Law: International Enforcement, vol 3 (Leiden, Martinus Nijhoff Publishers, 3rd edn., 2008) 581.

85 Ibid.

${ }^{86}$ M. Stevens, 'Due Process of Law: Procedural and Substantive Issues' $<$ http://faculty.ncwc.edu/mstevens/410/410lect06.htm > accessed 21 December 2011.

${ }^{87}$ See C. Buisman, M. Bouazdi and M. Costi, 'Principles of Civil Law' in K. Khan, C. Buisman and C. Gosnell (eds), Principles of Evidence in International Criminal Justice (Oxford, Oxford University Press, 2010) 16.

${ }^{88} \mathrm{Ibid} ., 14$.

${ }^{89}$ See Ohlin (n. 71) 94, 109.

${ }^{90}$ Ibid.

${ }^{91}$ See Bassiouni (n. 84) 593; see also J. D. Jackson and S. J. Summers, The Internationalization of Criminal Evidence: Beyond the Common Law and Civil Law Traditions (Cambridge, Cambridge University Press, 2012) 5. 
two ways. First, evidentiary rules are intended to regulate the use of information in court, while due process protections act as the checks and balances for this use. Consequently, due process rights can be seen as the main rationale behind evidentiary rules. Second, evidentiary rules may be viewed as the most obvious remedy for the infringement of due process rights, for instance the exclusion of any evidence obtained as a result of a due process violation..$^{92}$ Either way, the main goal of both sets of rules, evidence and due process, is finding the truth and generating the correct outcomes.

Because of the close connection between evidentiary rules and due process rights, the moderate due process thesis may affect domestic evidence law through those types of evidentiary rules that can be construed as a form of due process protection. The presumption of innocence, one of the six core elements of procedural fairness enumerated by Hildebrandt, as well as one of the key principles governing the application of the burden of proof, ${ }^{93}$ may be viewed as the main link between due process rights and evidentiary rules. Additionally, the following fair trial notions and rights consist of evidentiary rules, possibly causing the ICC to influence domestic evidence law through the principle of complementarity: (1) the equality of arms principle, consisting of rights such as access to evidence, equality in resources and means, including the right to counsel, the right to be present at trial, the right to be informed promptly of the charges, which includes the right to adequate time and facilities to prepare for trial and the right to disclosure, and related to the right to translated documents ${ }^{94}$; (2) the right to an expeditious trial and to be tried without undue delay, allowing for judicial powers such as setting the number of witnesses, determining the time available to the parties for presenting evidence, and exercising control over the questioning of witnesses ${ }^{95}$; (3) the right to a public trial, ensuring that justice is also seen to be done, but also related to dilemmas of witness protection, anonymous witnesses, and other protective measures for witnesses ${ }^{96}$; (4) the right to remain silent or the "right to lie" — in a common law system the accused has a right to remain silent but may choose to testify under oath, while in a civil law system the accused

\footnotetext{
92 See Bassiouni (n. 84) 597; see also May and Wierda (n. 26) 295.

${ }^{93}$ See May and Wierda (n. 26) 289.

94 Ibid., 266-277.

95 Ibid., 280.

${ }^{96}$ Ibid., 281-284.
} 
has no right to remain silent and may be questioned, but is not under oath, and therefore, has a "right to lie""97; and (5) the right to examine or have examined witnesses against him. ${ }^{98}$

If one or more of these evidentiary rules are too flawed or absent from a national criminal justice system, this could result in a gross violation of one of the core fair trial elements. However, the mere determination that a certain rule is absent or unsound should not suffice. As Gideon Boas notes, "[t]he nature of war crimes and their prosecution makes measures otherwise frowned upon in domestic criminal justice systems less egregious: retrospective extension of criminal provisions, extended jurisdiction, more relaxed evidentiary provisions may be considered appropriate and necessary (...)".99 Different standards may apply when dealing with international crimes. ${ }^{100}$

\subsection{Correction Factor: International Crimes and Fact-Finding}

There exists a caveat in relation to international crime prosecutions due to some practical difficulties. Naturally, the primary goal of any criminal trial is to determine whether a particular accused is guilty of the charges brought against him. ${ }^{101}$ However, the unique features of international criminal trials create numerous evidentiary challenges. ${ }^{102}$ Criminal evidentiary rules have "had to synthesize the rules

${ }^{97}$ Ibid., 289.

98 Ibid., 284-288.

${ }^{99}$ G. Boas, 'War Crimes Prosecutions in Australia and other Common Law Countries: Some Observations' (2010) 21 Criminal Law Forum 313, 327; see also May and Wierda (n. 26) 267, noting that "[i]n domestic common law courts, a question has arisen whether there should, in principle, be a relaxation of the technical rules of evidence in favor of the defense in war crimes trials, in order to ensure maximum protection against unjust conviction".

${ }^{100}$ Cf. Prosecutor v. Saif Al-Islam Gaddafi and Abdullah Al-Senussi (Application on behalf of the Government of Libya pursuant to Article 19 of the ICC Statute) ICC-01/11-01/11 (1 May 2012), para. 94 ("Even this Court with its considerable resources has required several years to bring accused persons to justice in less complex cases. Libya is meeting the requirements of due process in accordance with international standards, and cannot be held to a requirement of achieving swift justice in circumstances that neither other States nor the ICC itself are required to meet.").

${ }^{101}$ See Bassiouni (n. 84) 581, 589; see also Ohlin (n. 71) 93.

${ }^{102}$ See Bassiouni (n. 84) 581. 
to be found in these [domestic] laws and adapt them to the particular circumstances of the international criminal trial". 103

The first challenge these trials face is caused by the fact that evidence gathering is extremely difficult when dealing with mass atrocities due to the violent nature as well as the great magnitude of the situation under investigation. The scope of trials dealing with international crimes is much greater than those dealing with domestic crimes, causing a need for the rules to be adapted to fit the size of these trials. ${ }^{104}$ Secondly, in some instances the temporal and geographical distance from the scene of the crime may cause problems in addition to those of evidence gathering. Gathered evidence may be less reliable. And finally, the contextual elements of the crimes-the intent of the perpetrator, the context of a widespread attack, the context of an international armed conflict, etc., - give rise to evidentiary challenges, for these aspects are often difficult to establish in court. $^{105}$

Most if not all of these features are typical of trials where international crimes are prosecuted, whether in a domestic court or at an international tribunal, whereas they will be much less common in, or even completely absent from, trials prosecuting a "regular" domestic crime. Libya, for instance, is still coming to grips with the violence that took place in large parts of the country. ${ }^{106}$ Local prosecutors and investigators will face considerable challenges, as undoubtedly the ICC would as well, in gathering evidence. The crime scene encompasses most of the country, which has not yet recovered from Gaddafi's decades-long reign or the recent fighting, while the scope of the suspected crimes is tremendous compared to a simple domestic crime.

It is important to note that the assumption that international criminal trials are at least capable of determining who did what to whom during mass atrocities has been severely challenged in recent

${ }^{103}$ May and Wierda (n. 26) 2.

104 See Bassiouni (n. 84) 581.

${ }^{105}$ See for example N. A. Combs, 'Evidence' in W. Schabas and N. Bernaz (eds), Routledge Handbook of International Criminal Law (London, Routledge, 2010) 323; D. Vandermeersch, 'Prosecuting International Crimes in Belgium' (2005) 3 Journal of International Criminal Justice 400, 411.

106 In early 2012, there were still reports of violence breaking out in parts of Libya. See for example L. Stack, 'Pro-Government Libyan Militia Routed From a Qaddafi Bastion' New York Times (New York, 24 January 2012) < http://www.nytimes. $\operatorname{com} / 2012 / 01 / 25 /$ world/africa/pro-government-libyan-militia-routed-from-qaddafibastion.html?_r $=1 \&$ scp $=3 \&$ sq $=$ libya\&st $=$ cse $>$ accessed 25 January 2012 . 
years. ${ }^{107}$ Nancy Amoury Combs, for instance, has shown that international fact-finding is like gluing together grains of sand. Observing that prosecutors at today's international tribunals rely almost exclusively on eyewitness testimony, ${ }^{108}$ she describes the numerous problems haunting the reliability of witnesses. ${ }^{109}$ International criminal proceedings suffer from inaccurate fact-finding not only due to educational, linguistic, and cultural impediments but also because of witnesses perjury and errors in translation and investigation. Although domestic criminal jurisdictions are in a better position to tackle some of these problems (for instance, a possible Libyan prosecution of Saif al-Islam Gaddafi will most likely not be thwarted by linguistic or cultural impediments), domestic courts are bound to face some of the same challenges. Moreover, political factors can distort fact-finding in domestic jurisdictions, especially when trials are conducted in the same jurisdiction where the mass atrocities took place. This could be an issue of concern in Saif al-Islam's case, in addition to the expected challenges of trying a case in a post-conflict Libya, because tensions between the interim government and supporters of the late Muammar Gaddafi have not yet subsided. ${ }^{110}$

When prosecuting core international crimes, domestic courts will inevitably apply their own evidentiary rules. These can differ considerably between jurisdictions. The Anglo-American common law system and the Roman-Germanic civil law system are rather unalike in this respect; evidentiary rules play a significant role in a common law trial mostly because of the presence of a jury, while a civil law trial is generally much less constrained by evidentiary rules. Consequently, rules differ from legal system to legal system, from country to country, and even from state to state within one legal system. ${ }^{11}$ Nevertheless, certain evidentiary rules, as they relate to basic due

${ }^{107}$ See for example N. A. Combs, Fact-Finding Without Facts: The Uncertain Evidentiary Foundations of International Criminal Convictions (Cambridge, Cambridge University Press, 2010); A. Zahar, 'Witness Memory and the Manufacture of Evidence at the International Criminal Tribunals' in C. Stahn and L. van den Herik (eds), Future Perspectives on International Criminal Justice (The Hague, TMC Asser Press, 2010) 602.

108 See Combs, ibid., 6.

${ }^{109}$ Ibid., 21 et seq.; see also L. van den Herik, 'A Quest for Jurisdiction and an Appropriate Definition of Crime; Mpambara before the Dutch Courts' (2009) 7 Journal of International Criminal Justice 1117, 1130-1131.

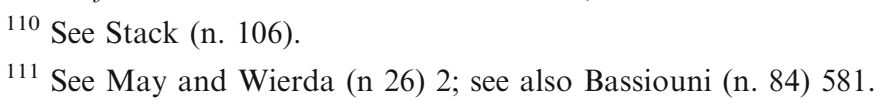


process protections, can be found in most legal systems in one form or another. For instance, the right of an accused to examine or have examined witnesses against him is one of the core elements of a fair trial and it can be found, albeit in varying forms, in the evidentiary rules of most legal systems of the world. ${ }^{112}$ Moreover, the ICC is not the only international institution that has to deal with such (domestic) differences. All the major international human rights treaties and their judicial bodies have had to deal with similar national divergences.

This article has established that the moderate due process thesis has a real and significant role to play when it comes to domestic proceedings. As shown by section III, the next step would be to ensure that the fact-finding and evidence debates within the context of domestic proceedings are conducted in compliance with the complementarity regime of the Rome Statute.

\section{CONCLUSION}

Saif al-Islam Gaddafi's case shows that the due process thesis discussion is still an important one. Fair trial concerns have been raised in relation to his case while local authorities seem eager to take action. However, the due process thesis as it stands is too broad. It is not in line with the Rome Statute's text or its drafters' intentions. Moreover, a liberal application of the classic due process thesis in admissibility determinations is unrealistic. It would swamp the ICC with cases the Court was never meant to deal with. This does not mean that the due process thesis discussion ought to be dismissed.

Although the mere lack of certain domestic fair trial rights should not be enough to make cases admissible under Article 17 or Article 20(3), there is a limit to what the Court can ignore. Instead of targeting every possible flaw in national due process protections, the moderate due process thesis focuses on core fair trial elements. These fundamental elements translate more universally to national jurisdictions without turning the ICC into a traditional human rights body. This would allow the Court to send an important message to

${ }^{112}$ See May and Wierda (n 26) 284-285; see also R. D. Friedman, 'The Confrontation Right Across the Systematic Divide' in J. Jackson et al. (eds), Crime, Procedure and Evidence in a Comparative and International Context: Essays in Honour of Professor Mirjan Damaska (Oxford, Hart Publishing, 2008) 262; C. M. Rohan, 'Rules Governing the Presentation of Testimonial Evidence' in K. Kahn et al. (n. 87); Jackson and Summers (n. 91), 24. 
the world: there is no justice without basic protection of the rights of the accused.

How strict should the ICC's assessment be with respect to evidentiary due process protections? Questions like these are food for future discussion with respect to the practical execution of the moderate due process thesis. National jurisdictions cannot be expected to meet higher standards than those asked of an international court or tribunal. Proving an international crime, as opposed to proving a domestic crime, is more challenging because of two fundamental differences: what needs to be proven is unique, i.e. the contextual elements typically found in international crime definitions, and how it needs to be proven is different - the practical circumstances leading to a high reliance on eyewitness testimony while the crime scene usually encompasses a post-conflict territory. When scrutinizing prosecutions and trials involving international crimes, these evidentiary challenges as well as other fact-finding impediments must be included in the equation for a fair admissibility assessment under the Rome Statute's complementarity regime.

This article has not suggested a radical change in the Court's admissibility determinations. It has proposed a process-oriented approach that is realistic in practice and cautious in its implementation. Perfect compliance with all international human rights standards is a utopian goal even for countries not torn up by violence. Yet, no defendant should be left to a Kafkaesque fate.

Open Access This article is distributed under the terms of the Creative Commons Attribution License which permits any use, distribution, and reproduction in any medium, provided the original author(s) and the source are credited. 